\title{
TEKNIS PEWADAHAN SAMPAH
}

\author{
Muhamad Afifaldi \\ Jurusan Teknik Lingkungan, Fakultas Arsitektur Lanskap dan Teknologi Lingkungan, \\ Universitas Trisakti, Jakarta, Indonesia
}

Email korespondensi: muhamad08212039@std.trisakti.ac.id

\begin{abstract}
ABSTRAK
Pengelolaan sampah perkotaan terdiri dari kegiatan pewadahan sampai dengan pembuangan akhir sampah. Pengelolaan harus bersifat terpadu dengan melakukan pemilahan sejak dari sumbernya. Salah satu teknis dalam kegiatan pengelolaan sampah adalah pewadahan. Pewadahan merupakan tahap awal dari rangkaian pengelolaan sampah yang nantinya akan berpengaruh terhadap kualitas dari tahap-tahap pengelolaan berikutnya. Pewadahan sampah yang kurang optimal akan menyebabkan timbulnya timbunan sampah liar yang berpotensi menimbulkan permasalahan pada lingkungan dan kesehatan masyarakat. Terdapat beberapa faktor yang mempengaruhi kegiatan pewadahan, antara lain ketersediaan fasilitas pewadahan, kegiatan pemilahan, serta prilaku dari masyarakat yang terlibat langsung dalam permasalahan berikut solusi penanganan sampah. Faktor ketersediaan fasilitas pewadahan sampah berpengaruh terhadap prilaku dari masyarakat, karena masyarakat terdorong berprilaku membuang sampah sembarangan akibat dari ketiadaan tempat sampah. Kegiatan pemilahan dilakukan sebagai dasar penentuan sistem managemen limbah padat yang didukung dengan data komposisi sampah. Komposisi sampah sendiri merupakan penggambaran dari masing-masing komponen yang terdapat pada sampah dan distribusinya. Kedua faktor sebelumnya sangat dipengaruhi oleh perilaku dari masyarakat yang ada, maka dari itu masyarakat perlu untuk memahami pentingnya kegiatan pemilahan di sumber serta dampak dari membuang sampah sembarangan. Kondisi tersebut yang mendorong karya ilmiah ini dibuat dengan maksud dan tujuan untuk mengevaluasi teknis pewadahan dalam pengelolaan sampah terhadap SNI 19-2454-2002 Tentang Tata Cara Teknik Operasional Pengelolaan Sampah Perkotaan bagian pewadahan.
\end{abstract}

\section{Kata Kunci: Sampah; Pewadahan; Teknis Operasional; Pengelolaan Sampah}

\section{PENDAHULUAN}

Seiring dengan perkembangan suatu wilayah, maka jumlah penduduk akan ikut bertambah, jumlah penduduk yang bertambah berkaitan dengan semakin banyaknya kebutuhan hidup perorangan yang harus terpenuhi, baik itu kebutuhan primer, sekunder maupun tersier. Produk dari kebutuhan tersebut mempunyai waktu pakai yang berbeda-beda, sehingga cepat atau lambat akan menjadi sampah. Meningkatnya jumlah sampah apabila tidak diimbangi dengan kemampuan pengelolaannya, maka berpotensi menimbulkan permasalahan pada lingkungan antara lain berkurangnya kenyamanan masyarakat akibat bau tidak sedap dan berkurangnya nilai estetika di kawasan tersebut. Selain permasalahan lingkungan, kesehatan masyarakat juga akan terganggu akibat penyakit yang dibawa oleh vektor dari timbunan sampah liar. Dari keseluruhan teknis operasional dalam pengelolaan sampah yaitu pewadahan, pengumpulan, pemindahan, pengangkutan, pengolahan, dan tempat pemrosesan akhir, salah satu aspek teknis operasional yang harus diperhatikan dalam pengelolaan sampah adalah teknis pewadahan, sebab kegiatan pewadahan merupakan tahap awal dari rangkaian pengelolaan sampah yang nantinya akan berpengaruh terhadap kualitas dari tahap-tahap pengelolaan berikutnya. Karya ilmiah ini dibuat dengan maksud dan tujuan untuk mengevaluasi teknis pewadahan dalam pengelolaan sampah terhadap SNI 19-2454-2002 Tentang Tata Cara Teknik Operasional Pengelolaan Sampah Perkotaan bagian pewadahan.

\section{TINJAUAN PUSTAKA}

\section{Definisi sampah}

Undang-Undang Nomor 18 tahun 2008 (UU Nomor 18 tahun 2008) tentang Pengelolaan Sampah mendefinisikan sampah sebagai sisa kegiatan sehari-hari manusia dan/atau proses alam yang berbentuk padat. Sampah dapat didefinisikan sebagai limbah yang bersifat padat terdiri dari 
bahan organik dan bahan anorganik yang dianggap tidak berguna lagi dan harus dikelola agar tidak membahayakan lingkungan dan melindungi investasi pembangunan (SNI 19-2454-2002).

\section{Komposisi Sampah}

Menurut SNI 19-3964-1994 tentang Metode Pengambilan dan Pengukuran Contoh Timbulan dan Komposisi Sampah Perkotaan, Komposisi sampah adalah komponen fisik sampah seperti sisasisa makanan, kertas-karton, kayu, kain-tekstil, karet-kulit, plastik, logam besi-non besi, kaca dan lain-lain. Sumber lain mengartikan komposisi sampah sebagai penggambaran dari masingmasing komponen yang terdapat pada sampah dan distribusinya.

Berdasarkan penelitian sebelumnya komposisi sampah terbesar di permukiman adalah sampah sisa makanan (sampah organik) dan sampah anorganik terbesar adalah plastik.

Pada penelitian lainnya, komposisi sampah sumber non permukiman didominasi organik jika berasal dari pasar, jalan, dan rumah makan, plastik jika berasal dari sekolah, pertokoan, lokasi wisata, dan hotel, serta kertas jika berasal dari kantor. Sisanya adalah logam, kaca, dan kain yang kurang dari $1 \%$.

Untuk keseluruhan komposisi sampah kota yaitu sampah permukiman dan non permukiman, penelitian lain menjelaskan secara umum komposisi sampah kota terdiri dari sampah organik $61,12 \%$, sampah anorganik 30,55 \%, sampah B3 3,7 \% dan residu 4,63\%.

Data mengenai komposisi sampah sangat diperlukan dalam penentuan sistem managemen limbah padat yang akan di terapkan, yaitu dalam penentuan teknis operasional pengelolaan sampah, salah satunya adalah pewadahan.

\section{Teknis Operasional Pengelolaan Sampah}

Pengelolaan sampah perkotaan terdiri dari kegiatan pewadahan sampai dengan pembuangan akhir sampah yang harus bersifat terpadu dengan melakukan pemilahan sejak dari sumbernya (SNI 19-2454-2002). Pengelolaan sampah meliputi kegiatan pewadahan, pengumpulan, pemindahan, pengangkutan, pengolahan dan pemrosesan. kegiatan pengelolaan sampah disesuaikan berdasarkan kondisi wilayah dan daya dukung lingkungan di wilayah tersebut (UU Nomor 18 tahun 2008). Berdasarkan SNI 19-2454-1991 rnengenai Tata Cara Pengelolaan Teknik Sampah Perkotaan, Teknis Operasional Pengelolaan Sampah Perkotaan dimulai dari pewadahan sampah, yaitu aktivitas menampung sampah sementara dalam suatu wadah individual atau komunal di tempat sumber sampah, pengumpulan sampah adalah aktivitas penanganan yang tidak hanya mengumpulkan sampah dari wadah individual dan atau dari wadah komunal (bersama) melainkan juga mengangkutnya ke tempat terminal tertentu, baik dengan pengangkutan langsung maupun tidak langsung, pemindahan sampah adalah kegiatan memindahkan sampah hasil pengumpulan ke dalam alat pengangkut untuk dibawa ke tempat pembuangan akhir, pengangkutan sampah adalah kegiatan membawa sampah dan lokasi pemindahan langsung dan sumber sampah rnenuju ke tempat pembuangan akhir, pengolahan sampah adalah suatu proses untuk mengurangi volume sampah dan atau mengubah bentuk sampah menjadi yang bermanfaat, antara lain dengan cara pembakaran, pengomposan, pemadatan, penghancuran, pengeringan,dan pendaur ulangan, pemilahan sampah adalah proses pemisahan sampah berdasarkan jenis sampah yang dilakukan sejak dari sumber sampai dengan pembuangan akhir, dan pembuangan akhir sampah adalah tempat dimana dilakukan kegiatan untuk mengisolasi sampah sehingga aman bagi lingkungan. Pewadahan sebagai kegiatan awal pengelolaan sampah memiliki peranan penting guna menunjang teknis operasional kedepannya. Terdapat dua jenis pewadahan yaitu pewadahan individual dan pewadahan komunal. Wadah individual ditempatkan di halaman muka, sedangkan untuk sumber sampah dari hotel dan restoran, wadah sampah ditempatkan di halaman belakang. Untuk wadah komunal, wadah ditempatkan dengan ketentuan sedekat mungkin dari sumber sampah, tidak mengganggu pemakai jalan atau sarana umum Iainnya, di luar jalur lalu lintas, pada lokasi yang mudah untuk pengoperasiannya, di ujung gang kecil, di sekitar taman dan di pusat keramaian. Persyaratan bahan yang dapat digunakan untuk pewadahan diantaranya tidak mudah rusak dan tahan air, ekonomis, mudah didapatkan atau dibuat oleh masyarakat, dan mudah digunakan. Pengadaan wadah individual dilakukan oleh pribadi/instansi/pengelola, sedangkan untuk wadah komunal 
pengadaan dilakukan oleh instansi pengelola. Teknis pewadahan yang ideal harus berdasarkan keseimbangan antara sampah yang ditimbulkan dan perilaku masyarakat. Untuk kebutuhan, kapasitas dan jumlah wadah disesuaikan dengan timbulan sampah yang dihasilkan oleh sumber sampah dengan periode pengumpulan sampah yang dilakukan. Kegiatan pemilahan harus dilakukan mulai dari sumber dan selanjutnya ditempatkan sesuai dengan jenis sampah yang telah terpilah, yaitu sampah organik seperti daun sisa, sayuran, kulit buah lunak, sisa makanan, dengan warna gelap, sampah anorganik seperti gelas, plastik, logam, dan lainnya, dengan wadah warna terang, dan sampah bahan berbahaya beracun (B3) rumah tangga dengan warna merah yang diberi lambang khusus atau semua ketentuan yang berlaku.

\section{Evaluasi Teknis Pewadahan}

Pada penelitian yang telah dilakukan, faktor penyebab penerapan teknis pewadahan tidak sesuai dengan SNI 19-2454-2002 adalah karena masyarakat kurang memahami konsep pemilahan dan perilaku dari masyarakat tersebut yang membuang sampah sembarangan akibat dari kurangnya fasilitas pewadahan sampah yang tersedia.

Menyikapi hal tersebut, terdapat beberapa upaya yang dapat dilakukan berupa memberikan pembinaan terhadap masyarakat mengenai pemilahan sampah di sumber serta dampak dan bahaya dari membuang sampah sembarangan, wadah sampah juga harus disesuaikan dengan timbulan sampah yang dihasilkan dan periode pengumpulan atau pengangkutan sampah. Namun dari penelitian lainnya didapat bahwa masyarakat menyatakan tidak sempat, malas, sulit memisahkan, dan belum menyadari padahal sudah mengetahui dan menerima sosialisasi. Hasil tersebut menunjukkan bahwa faktor predisposisi yang membentuk perilaku masyarakat mengarah ke perilaku negatif.

Kegiatan pemilahan di sumber sesuai dengan SNI 19-2454-2002 bagian pewadahan penting untuk dilakukan guna mendukung teknis pewadahan sebab berdasarkan penelitian yang telah dilakukan, penggunaan wadah antara sampah organik dan anorganik sebaiknya dipisahkan karena dapat meningkatkan nilai estetika dan mencegah penyakit yang akan ditimbulkan. Kapasitas wadah antara sampah organik dan anorganik harus memiliki kapasitas yang sama. Pengaruh warna pada wadah juga berdampak positif karena dapat meningkatkan minat masyarakat untuk membuang sampah sesuai dengan tempat yang telah disediakan.

\section{PENUTUP}

Berdasarkan uraian diatas maka diperlukan penelitian dan perencanaan lebih lanjut terhadap teknis operasional dalam pengelolaan sampah khususnya bagian pewadahan guna menindak lanjuti permasalahan ketersediaan wadah, kegiatan pemilahan, dan prilaku dari masyarakat yang terlibat langsung dalam permasalahan berikut solusi penanganan sampah.

\section{DAFTAR PUSTAKA}

Indrawati, Dwi dkk. 2013. Perencanaan Teknis Operasional Pengelolaan Sampah Pemukiman Di Kecamatan Jatiasih, Kota Bekasi. Indonesian Journal of Urban and Environmental Technology. 4(6): $101-107$.

DOI : 10.25105/urbanenvirotech.v6i4.706

Pratiwi, Puspa Shinta dkk. 2018. Evaluasi Dan Perencanaan Aspek Teknik Operasional

Pengelolaan Sampah Kota Yogyakarta. Jurnal Universitas Islam Indonesia: Yogyakarta.

J.B. Israwati dkk. Rencana Peningkatan Teknis Operasional Pengelolaan Persampahan Di Kota Bau - Bau. Jurnal Teknik Lingkungan ITS : Surabaya.

Guritno, M. Ganang dkk.

Saugi, Agung Ananda. 2016. Evaluasi Teknik Operasional Persampahan Kecamatan Sambas. Jurnal Teknik Lingkungan Universitas Tanjungpura: Pontianak

Darmawan, Awan. 2014. Perilaku Masyarakat dalam Mengelola Sampah di Kota Bima Nusa

Tenggara Barat. Jurnal Pembangunan Wilayah dan Kota. Biro Penerbit Planologi Undip. 10(2): $175-186$. 
Ramandhani, Tri Astuti. 2011. Analisis Timbulan Dan Komposisi Sampah Non Permukiman Di Wilayah Kabupaten Kulon Progo, Yogyakarta. Jurnal Universitas Indonesia : Depok.

Ikhsandri. 2014. Kajian Infrastruktur Pengolahan Sampah Di Kawasan Berkembang Jakabaring Kelurahan 15 Ulu Kota Palembang. Jurnal Teknik Sipil dan Lingkungan. 1(2) : ISSN $2355-374 X$. 